\title{
Catechins induced acute promyelocytic leukemia cell apoptosis and triggered PML-RARa oncoprotein degradation
}

\author{
Li Zhang ${ }^{1 \dagger}$, Qiu-Sheng Chen ${ }^{1 \dagger}$, Peng-Peng Xu' ${ }^{1}$, Ying Qian ${ }^{1}$, Ai-Hua Wang ${ }^{1}$, Dan Xiao ${ }^{1}$, Yan Zhao ${ }^{1}$, Yan Sheng ${ }^{1}$, \\ Xiang-Qin Wen ${ }^{1}$ and Wei-Li Zhao ${ }^{1,2^{*}}$
}

\begin{abstract}
Background: It has recently been reported that the extracts of green tea polyphenol have cancer preventive effects. In this study, we investigated the effect of the natural composition from green tea leaves Catechins on acute promyelocytic leukemia (APL).

Methods: In vitro, APL cell lines NB4, retinoic acid-resistant NB4-R1 and NB4-R2 were treated with different concentrations of Catechins. Cell viability and cell apoptosis were analyzed using MTT assay and flow cytometric assay, respectively. Expression of proteins related to apoptosis and PML-RARa oncoprotein were assessed by Western blot. In vivo anti-tumor activity of Catechins was examined in nude mice xenografted with NB4 cells and in situ cell apoptosis was detected by terminal deoxytransferase-catalyzed DNA nick-end labeling assay.

Results: Catechins at micromolar concentration levels significantly inhibited APL cell proliferation and induced cell apoptosis, in association with mitochondria damage, ROS production and caspase activation. The anti-apoptotic $\mathrm{BCl}-2$ family member $\mathrm{BCl}-\mathrm{xL}$ was down regulated, with pro-apoptotic member Bax remaining unchanged. Moreover, Catechins induced the degradation of PML-RARa oncoprotein. Catechins-mediated apoptotic effect was also observed in primary APL cells without affecting normal hematopoietic progenitor cells. In the murine xenograft model, Catechins remarkably inhibited tumor growth and induced in situ leukemic cell apoptosis.
\end{abstract}

Conclusions: Catechins might be a potential candidate for APL treatment by activating intrinsic apoptotic pathway and targeting PML-RARa oncoprotein.

Keywords: Catechins, Acute promyelocytic leukemia, Apoptosis, PML-RARa oncoprotein

\section{Background}

Acute promyelocytic leukemia (APL) accounts for approximately $10 \%$ of all acute myeloid leukemias and is characterized by a specific chromosomal translocation $t$ $(15 ; 17)$, resulting in the fusion of promyelocytic leukemia (PML) gene to retinoic acid receptor (RAR $\alpha$ ) gene. The expression of PML-RAR $\alpha$ chimeric protein plays a central role in leukemogenesis, including arrest of differentiation

\footnotetext{
* Correspondence: zhao.weili@yahoo.com

${ }^{\dagger}$ Equal contributors

'State Key Laboratory of Medical Genomics, Shanghai Institute of Hematology, Department of Hematology, Rui Jin Hospital, Shanghai Jiao Tong University School of Medicine, 197 Rui Jin Er Road, Shanghai 200025, China

${ }^{2}$ Pôle de Recherches Sino-Français en Science du Vivant et Génomique, Laboratory of Molecular Pathology, Shanghai, China
}

and deregulation of apoptosis [1,2]. The currently used agents all-trans retinoic acid (ATRA) and arsenic trioxide $\left(\mathrm{As}_{2} \mathrm{O}_{3}\right)$ directly target PML-RAR $\alpha$ oncoprotein and dramatically improve the clinical outcome of APL patients [3-13]. This greatly encourages further discovery of potential molecular target-based agents, particularly nature products, on APL treatment.

Epidemiologic studies have already shown that green tea consumption is beneficial to health and can reduce the incidence of cancer [14]. Recently, green tea products have attracted more attention because of their anti-cancer effects revealed in experimental tumor models [15-32]. Catechins is the main component extracted from the green tea leaves, including epipallocatechin gallate (EGCG), epicatechin gallate (ECG), epigallocatechin 
(EGC) and epicatechin (EC) etc. [33]. Catechins prove to be inexpensive, safe, and can be administrated orally. Therefore, whether Catechins possesses anti-leukemia capability is of great interest to leukemia treatment.

In this study, we assessed the effect of Catechins on both retinoic acid (RA)-sensitive and -resistant APL cell lines [34-36], as well as on primary APL cells and on a murine xenograft APL model. The Catechins-induced apoptosis of APL cells and expressions of related proteins (Bcl-2, Bcl-xL, Bax and PML-RAR $\alpha$ ) were also investigated to explore possible molecular mechanism.

\section{Results}

\section{Catechins inhibited cell growth and induced cell} apoptosis in human APL cell lines

Using MTT assay, we determined the effect of Catechins on various human leukemia cell lines. The IC50 value (median inhibitory concentration) of Catechins in these leukemia cells were calculated after 24 hours of treatment. Catechins exerted substantial growth inhibition in APL cell lines (NB4-R1, NB4-R2 and NB4), Kasumi-1 cells and K562 cells (Figure 1A). However, the sensitivity of U937 cells to Catechins was relatively lower, with IC50 higher than $200 \mu \mathrm{M}$.

The response curves of NB4-R1, NB4-R2 and NB4 to Catechins were shown in Figure 1B. Catechins inhibited cell growth in a time- and dose-dependent manner. To confirm whether the growth inhibition of Catechins was caused by apoptosis, cell morphology and AnnexinV-FITC/PI double staining were performed. Morphologically, cell apoptosis was observed at 24 hours of treatment with Catechins, showing characteristic changes, such as chromatin condensation, nuclear fragmentation, and formation of apoptotic bodies (Figure 1C). The percentage of Annexin $\mathrm{V}$-positive cells, reflecting those undergoing apoptosis, was gradually increased during treatment (Figure 1D). Cell cycle analysis also revealed a time-dependent elevation of sub-G1 cell content, consistent with Catechins-induced APL cell apoptosis (Figure 1E).

\section{Catechins-induced apoptosis was associated with mitochondria damage, ROS production and caspase activation}

The anti-leukemia effect of APL cell lines treated by ATRA $(1 \mu \mathrm{M}), \mathrm{As}_{2} \mathrm{O}_{3}(1 \mu \mathrm{M})$, EGCG $(100 \mu \mathrm{M})$, ECG $(100 \mu \mathrm{M})$, EGC $(100 \mu \mathrm{M})$ and Catechins $(100 \mu \mathrm{M})$ were further compared. As shown in Figure 2A, Catechins, more effiently than its main active components, exhibited a significant growth inhibitory effect as observed in the $\mathrm{As}_{2} \mathrm{O}_{3}$ group, indicating that Catechins was equally effective as $\mathrm{As}_{2} \mathrm{O}_{3}$.

NB4 cells were then treated with Catechins, either alone or combined with pan-caspase inhibitor ZVAD-FMK. Catechins-induced cell growth inhibition could be significantly abrogated by ZVAD-FMK treatment, referring Catechins as an apoptotic-dependent cell death inducer

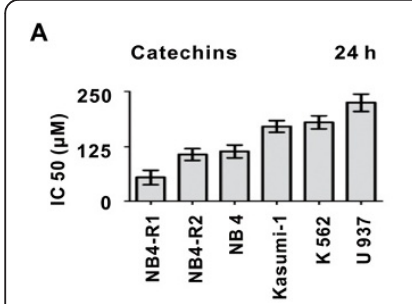

C

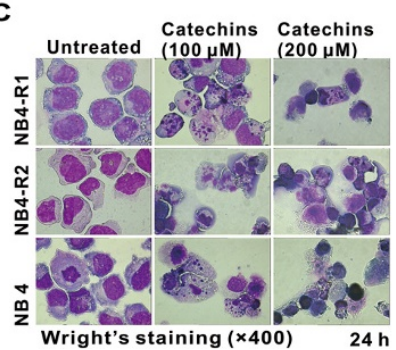

B

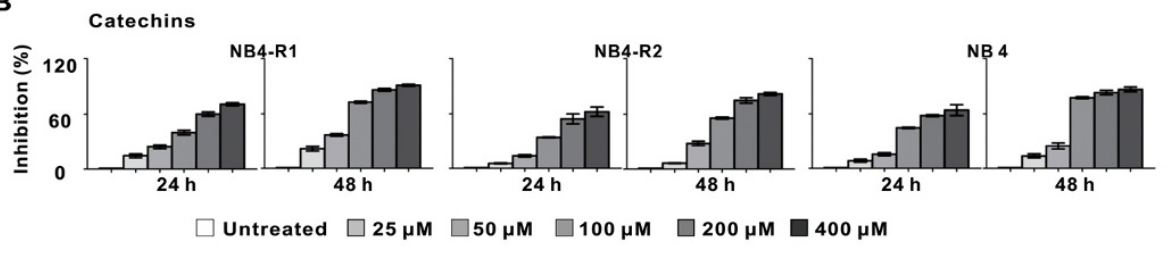

D

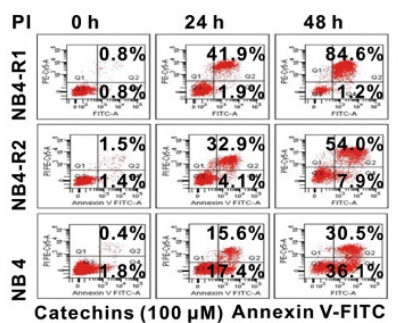

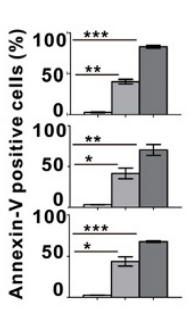

E

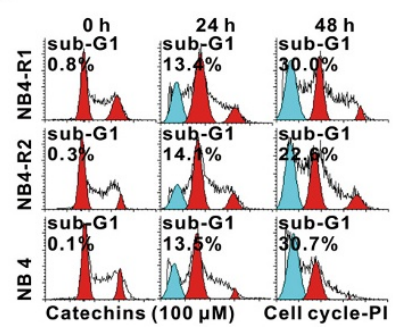

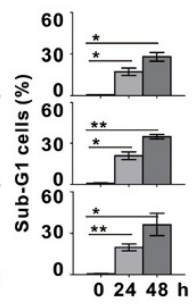

Figure 1 The effect of Catechins treatment on growth and apoptosis of human leukemia cell lines. (A) IC50 results obtained from MTT assay in leukemia cell lines treated with Catechins at $24 \mathrm{~h}$. The IC50 values of NB4-R1, NB4-R2 and NB4 cells were below 125 MM. (B) The growth inhibition of NB4-R1, NB4-R2 and NB4 cells treated with Catechins for 24 and $48 \mathrm{~h}$. Reduced cell viability were detected in APL cell lines from

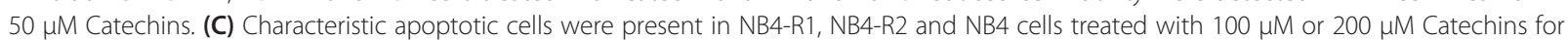
$24 \mathrm{~h}$. (D) Detection of apoptotic cells by Annexin V-FITC/PI double staining in NB4-R1, NB4-R2 and NB4 cells treated with 100 HM Catechins for 24 and $48 \mathrm{~h}$. Catechins treatment increased the percentages of Annexin-V+/PI- cells (lower right quadrant) and Annexin-V+/PI + cells (upper right quadrant). (E) Contribution of nuclear DNA content in NB4-R1, NB4-R2 and NB4 cells treated with $100 \mu \mathrm{M}$ Catechins for $24 \mathrm{~h}$ and $48 \mathrm{~h}$. Significantly increased sub-G1 cells were observed. ${ }^{*} \mathrm{P}<0.05,{ }^{* *} \mathrm{P}<0.01,{ }^{* *} \mathrm{P}<0.001$ comparing with the untreated cells. 


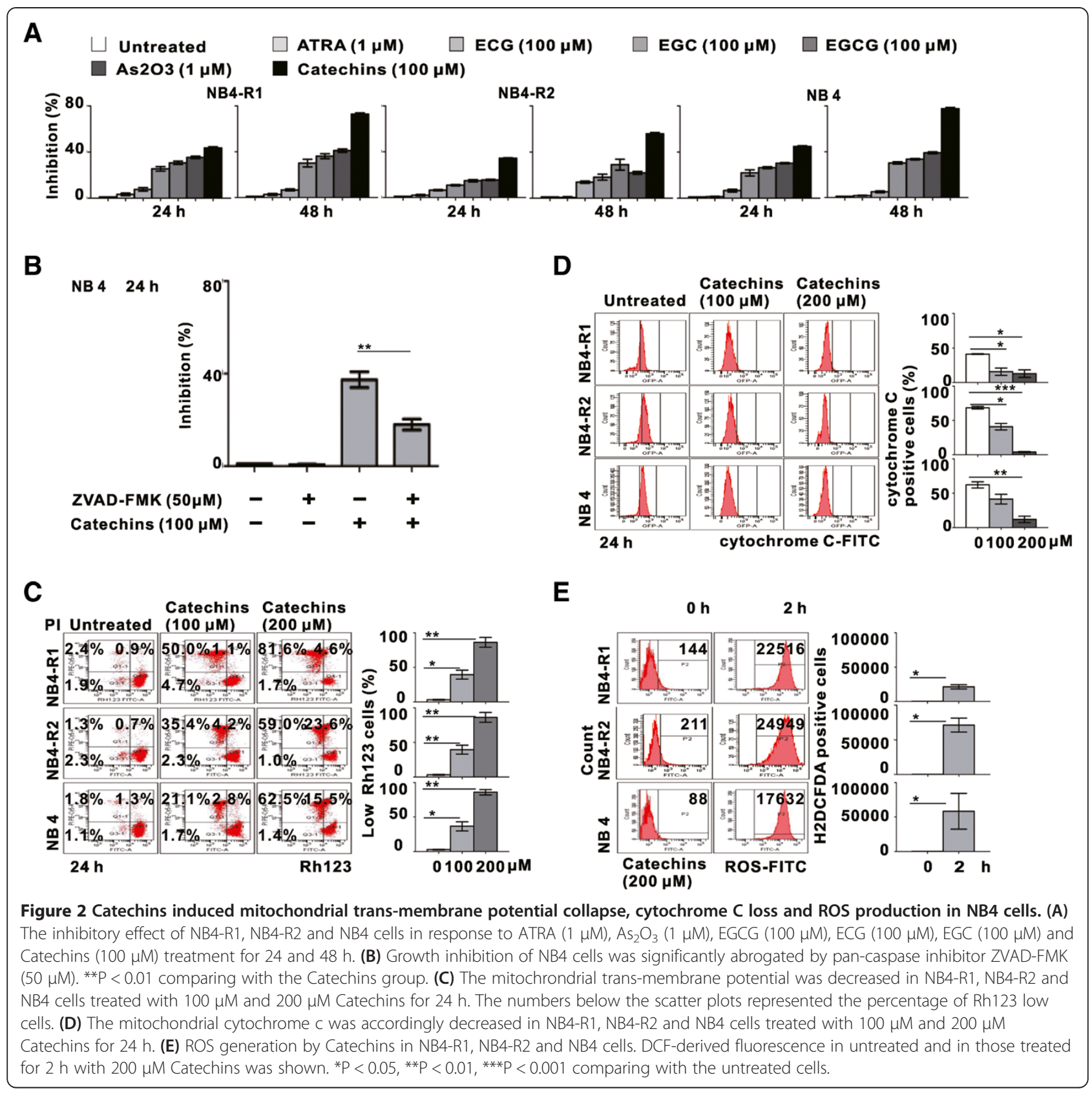

(Figure 2B). Marked dissipation of mitochondrial transmembrane potential $(\Delta \psi \mathrm{m})$ (Figure $2 \mathrm{C}$ ) and subsequent decreased mitochondrial cytochrome c (Figure 2D) were observed in NB4-R1, NB4-R2 and NB4 cells treated with Catechins in a dose-dependent manner.

To investigate whether ROS level was also affected by Catechins, we also used flow cytometric analysis with a cell-permeable dye, $\mathrm{H}_{2}$ DCFDA, which is specifically cleaved to emit a fluorescence wave length in the presence of ROS. Treatment with $200 \mu \mathrm{M}$ Catechins for 2 hours resulted in a significant elevation of intracellular ROS in NB4-R1, NB4-R2 and NB4 cells (Figure 2E).
Catechins acted on intrinsic apoptotic pathway through downregulation of $\mathrm{BCl}-\mathrm{xL}$ and induced apoptosisindependent degradation of PML-RARa oncoprotein

In parallel to $\Delta \psi \mathrm{m}$ loss, western blot analysis showed that Catechins significantly induced activation of caspase-3, -8 and -9 in NB4 cells. Correspondingly, PARP was cleaved to an $89-\mathrm{kDa}$ fragment by Catechins treatment at 24 hours (Figure 3A). These data suggested that Catechins induced cell apoptosis through an intrinsic mitochondrial pathway and was dependent on caspase activation.

Mitochondrial membrane permeability is directly controlled by Bcl- 2 family proteins, which are the central 
A

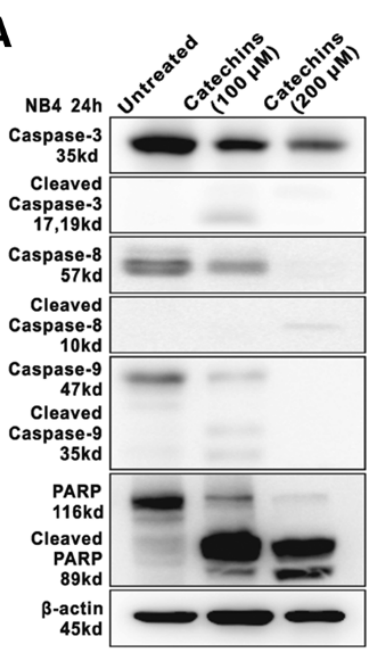

B

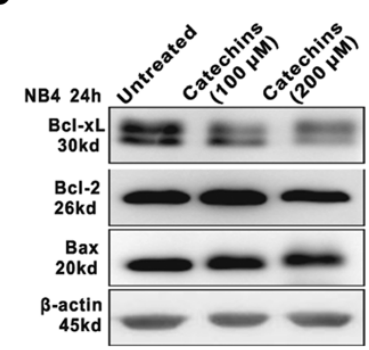

C

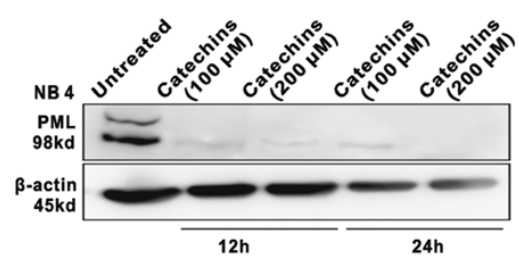

D

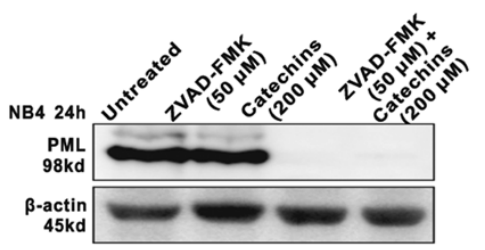

E

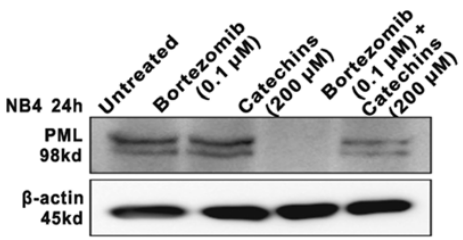

Figure 3 Catechins induced caspase activation, Bcl-xL downregulation, and the degradation of PML-RARa fusion protein in NB4 cells. (A) Western blot analysis of caspase-3, -8, -9, and PARP in NB4 cells treated with $100 \mu \mathrm{M}$ and $200 \mu \mathrm{M}$ Catechins for $24 \mathrm{~h}$. Caspase-3 was activated with caspase- 8 and caspase- 9 and PARP cleaved. (B) The expression of BCl-2, Bcl-xL and Bax protein were determined by Western blot. $\mathrm{BCl}-\mathrm{xL}$ expression was reduced in NB4 cells treated with $100 \mu \mathrm{M}$ and $200 \mu \mathrm{M}$ Catechins for $24 \mathrm{~h}$. (C) PML-RARa was decreased upon treatment with $100 \mu \mathrm{M}$ and $200 \mu \mathrm{M}$ Catechins at $12 \mathrm{~h}$ and $24 \mathrm{~h}$. (D and E) PML-RARa was not affected by pan-caspase inhibitor ZVAD-FMK (50 $\mu \mathrm{M}$ ), but partially blocked by proteasome inhibitor bortezomib $(0.1 \mu \mathrm{M})$. Three independent experiments were performed and representative results were shown.

regulators of caspase activation. To determine whether Catechins impair the mitochondria through affecting these Bcl-2 family members, the expression of antiapoptotic factor Bcl-2 and Bcl-xL, as well as pro-apoptotic factor Bax were investigated in NB4 cells at 24 hours of incubation with Catechins. Bcl-xL expression were decreased, while no significant change was detected on $\mathrm{Bcl}-2$ and Bax expression (Figure 3B).

Western blot analysis confirmed that untreated NB4 cells expressed the PML-RAR $\alpha$ oncoprotein. Catechins treatment induced the degradation of PML-RAR $\alpha$ at 12 and 24 hours (Figure 3C). Independent on its apoptotic action, Catechins-mediated degradation of PMLRAR $\alpha$ oncoprotein was not affected by co-treatment with pan-caspase inhibitor ZVAD-FMK (Figure 3D). However, the degradation process could be, at least partially, blocked by proteasome inhibitor bortezomib, indicating that it was dependent on proteasome pathway (Figure 3E).
Catechins induced apoptosis of leukemia cells from $t$ $(15 ; 17)$ APL patients and did not affect the proliferation capacity of normal hematopoietic progenitor cells

Treatment with Catechins significantly inhibited cell growth and resulted in more than $50 \%$ cell inhibition at 48 hours in primary leukemia cells from three APL patients with $\mathrm{t}(15 ; 17)$ (Figure 4A). Representative morphological changes of apoptosis were present in the Catechins group (Figure 4B). Annexin V-PI double staining assay also revealed increased apoptosis in Catechins-treated cells, as compared to the untreated cells (Figure 4C). The ROS production in APL cells treated with $200 \mu \mathrm{M}$ Catechins for 2 hours was significantly higher than that in the untreated cells (Figure 4D). Treatment with $100 \mu \mathrm{M}$ and $150 \mu \mathrm{M}$ Catechinsafter 24 hours significantly induced the degradation of PML-RAR $\alpha$ oncoprotein (Figure 4E).

Of note, as determined by MTT assay, proliferation of $\mathrm{CD}_{3}{ }^{+}$cells isolated from human cord blood was not 
A

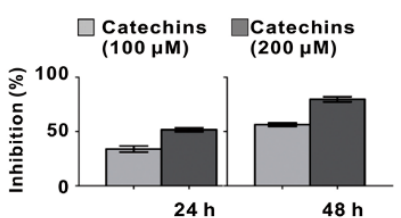

B

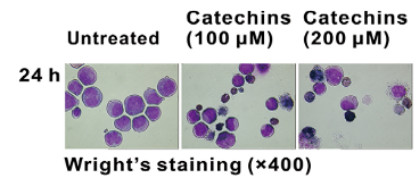

C

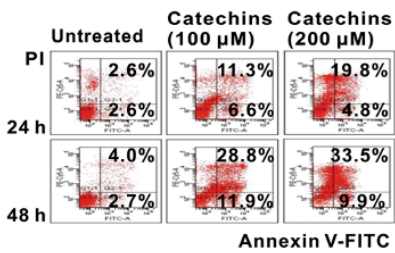

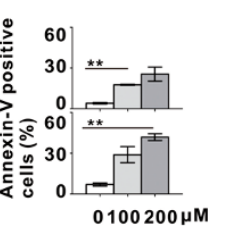

D

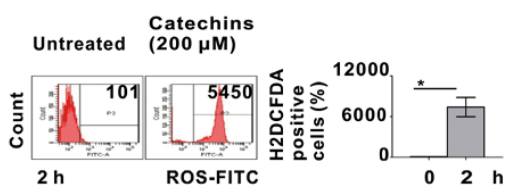

$\mathbf{E}$

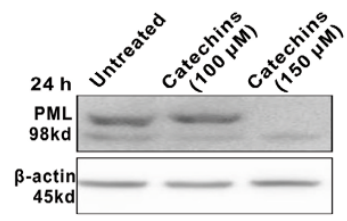

$\mathbf{F}$

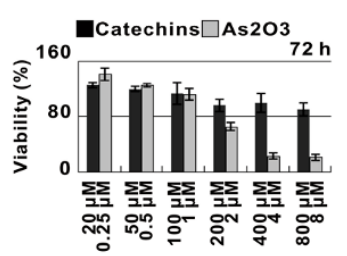

Figure 4 Catechins induced apoptosis in primary APL cells without affecting the proliferation capacity of normal hematopoietic progenitor cells. (A) Catechins inhibited growth of primary leukemia cells from patients with APL by MTT assay. Cells were treated with $100 \mu \mathrm{M}$ and $200 \mu \mathrm{M}$ Catechins for $24 \mathrm{~h}$ and $48 \mathrm{~h}$. (B) Catechins induced apoptosis of primary leukemia cells from three patients by morphological study. Cells were treated with $100 \mu \mathrm{M}$ and $200 \mu \mathrm{M}$ Catechins for $24 \mathrm{~h}$. (C) Apoptosis was evaluated by Annexin V/PI double staining and showed the fold-increase of apoptotic cells in all three cases. Cells were treated with $100 \mu \mathrm{M}$ and $200 \mu \mathrm{M}$ Catechins for 24 and $48 \mathrm{~h}$. ${ }^{*} \mathrm{P}<0.01$ comparing with the untreated cells. (D) Intracellular levels of ROS were measured by flow cytometry in all three cases. Cells were treated with $200 \mu \mathrm{M}$ Catechins for $2 \mathrm{~h}$. *P $<0.05$ comparing with the untreated cells. (E) The PML-RARa oncoprotein was degraded in primary leukemia cells treated with $100 \mu \mathrm{M}$ and $150 \mu \mathrm{M}$ Catechins for $24 \mathrm{~h}$. (F) The proliferation of normal hematopoietic progenitor cells was not inhibited by Catechins up to $800 \mu \mathrm{M}$. CD34+ cells enriched from cord blood samples $(n=3)$ were cultured in the presence of Catechins at the indicated concentrations for $72 \mathrm{~h}$. The cell viability was measured by MTT assay.

affected even at the concentrations up to $800 \mu \mathrm{M}$ after 72 hours of treatment, suggesting that primary APL cells responded to Catechins in a similar way as NB4 cells and Catechins exerted no severe cytotoxic effect on normal hematopoietic precursors (Figure 4F).

\section{Catechins inhibited tumor growth and induced in situ leukemia cell apoptosis in a murine xenograft model} We established the human APL model in nude mice using NB4 cells. NB4 cells $\left(1 \times 10^{7}\right)$ were inoculated subcutaneously into the nude mice (Day 0 ). The latency of tumor formation at the site of injection was approximately 6-8 days. The mice were then treated with Catechins $(10 \mathrm{mM})$ as the only drinking from Day 10 and tumor volume was measured daily until Day 31. Compared with the untreated group, Catechins significantly reduced the tumor size $(\mathrm{P}<0.01)$ (Figure 5A). During treatment, Catechins-treated mice appeared with better condition than those of the control group. Pathologic analysis at autopsy revealed no tumor infiltration in any of the organs (data not shown).

Tumor cell apoptosis was evaluated by TUNEL assay. Comparing with the control mice, a significantly increased number of apoptotic cells was observed in the Catechins- treated mice $(\mathrm{p}<0.001)$ (Figure $5 \mathrm{~B})$, providing in vivo evidence of Catechins-induced APL cell apoptosis.

\section{Discussion}

Catechins is the full extracts of the natural green tea leaves. EGCG is the main component of Catechins and has been shown with anti-tumor activities in many types of cancers [15-32]. Here we reported the first time, that Catechins possessed an anti-proliferative effect on leukemia cells, especially on $t(15 ; 17)$ leukemia cells. This was observed not only in well-established APL cell lines and primary tumor samples of APL patients, but also in a murine xenograft tumor model of $t(15 ; 17)$ leukemia. Equally effective to targeted agents commonly used in APL as $\mathrm{As}_{2} \mathrm{O}_{3}$, Catechins, with similar bioactivity but much less expensive than EGCG, could be a potential candidate to treat APL.

Catechins possesses the anti-leukemic activity mainly due to the induction of apoptosis, which has been demonstrated by morphological features and increase of apoptotic cells both in vitro and in vivo. Caspase-3 activation is essential for leukemia cell apoptosis. In our study, Catechins generated a cleavage of caspase- 3 and 

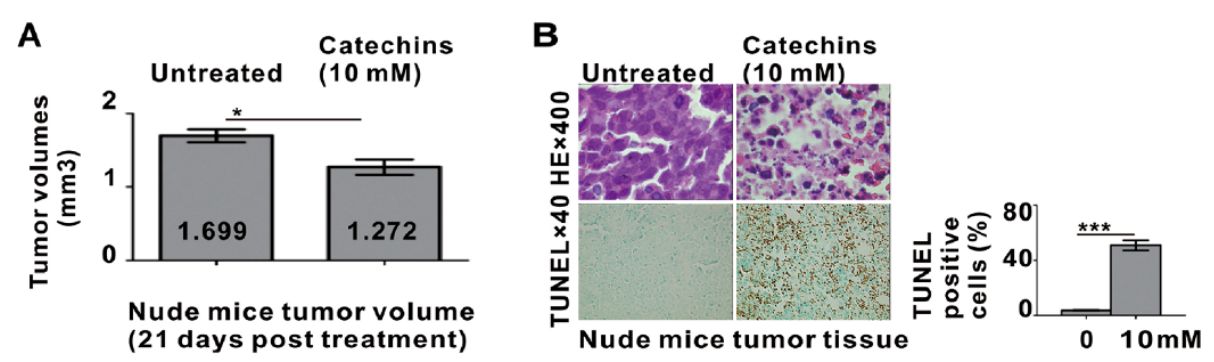

Figure $\mathbf{5}$ In vivo effect of Catechins on murine models of APL. (A) Catechins decreased the tumor volumes in a murine xenograft model. Nude mice were received 3 Gy radiation one day before subcutaneous injection with NB4 cells. The treatments began 10 days later including control diluent $(n=5)$ and Catechins $(10 \mathrm{mM})(n=5)$ daily for 21 days. The tumor volumes of control mice and Catechins-treated mice on Day 31 were measured. Catechins significantly reduced the xenograft tumor volumes ( $\left.{ }^{*} \mathrm{P}<0.05\right)$. (B) Apoptotic cells detected by TdT-FragEL ${ }^{\mathrm{TM}} \mathrm{DNA}$

Fragmentation Detection kit were calculated. A significantly increased number of apoptotic cells was observed in the Catechins group, comparing with the untreated group ${ }^{* * *} \mathrm{P}<0.001$.

subsequent cleavage of the DNA repair enzyme PARP, the hallmark of apoptosis. Bcl-xL, as an important antiapoptotic protein of Bcl-2 family [37], was accordingly reduced by Catechins, further implying that intrinsic apoptotic pathway was involved in Catechins-induced apoptosis. This is in consistent with previous study of EGCG on many solid tumors, such as hepatocellular carcinoma, chondrosarcoma, and endometrial cancer [38-42]. Moreover, Catechins also changed the intracellular redox status and regulatedthe mitochondria pathway through elevating ROS, similar to EGCG [43]. The intracellular redox status, depending on ROS generation, is critical in keeping mitochondria stable. Elevation of intracellular ROS production was also shown during EGCG-induced apoptosis in tumor cell lines mentioned above [38-40]. Therefore, Catechins induced APL cell apoptosis through intrinsic apoptotic pathway via $\mathrm{Bcl}-\mathrm{xL}$ downregulation and ROS induction.

Interestingly, PML-RAR $\alpha$ oncoprotein can be directly targeted by Catechins. In hepatocellular carcinoma, EGCG lowers the expression of phosphorylated STAT3 protein and inhibits the expression of multiple genes including Bcl-xL [44]. In an apoptosis-independent manner, functional modulation of RARA and PML-RAR $\alpha$ by the peptidyl-prolyl-isomerase Pin1, or the the mitogenactivated protein kinase, p38 $\alpha$ correlates with stabilization/ degradation of PML-RAR $\alpha$ via the proteasome pathway $[45,46]$. Our data also revealed that Catechins acted on PML-RAR $\alpha$, at least partially, in a proteasome-dependent manner. Therefore, PML-RAR $\alpha$ oncoprotein may also represent the target of the Catechins treatment in APL, although the precise mechanism of action in Catechinsinduced PML-RAR $\alpha$ degradation need further investigation.

Our findings not only suggested possible mechanisms of Catechins in the apoptosis-regulatory pathways in APL cells, but also provide a model for studying Catechins in cancer treatment. Since green tea extracts have already entered phase I trials in patients with solid tumors [47-49], similar clinical trials would be necessary to further evaluate the anti-leukemic effect of Catechins on acute leukemias.

\section{Conclusions}

In summary, our study demonstrated that Catechins effectively induced apoptosis of APL cells through induction of intrinsic apoptotic pathway and degradation of PML-RAR $\alpha$ oncoprotein. Catechins may thus be a potential apoptosis inducer and therapeutic agent for APL treatment.

\section{Materials and methods Reagents}

Catechins (Pharmanex, USA, each capsule contains EGCG 95 mg, ECG 37 mg, EGC 15 mg), EGCG (SigmaALDRICH, E4143, C22H18O11, MW: 458.37), ECG (Shanghai Winherb Medical Technology Co., Ltd, C22H18O10, MW: 442.37) and EGC (Shanghai Winherb Medical Technology Co., Ltd, C15H14O7, MW: 306.27) were prepared at the concentration of $10 \mathrm{mM}$ with RPMI 1640 medium (GIBCO-BRL, Grand Island, NY, USA). Arsenic trioxide $\left(\mathrm{As}_{2} \mathrm{O}_{3}\right.$, Sigma-ALDRICH, A1010, MW: 197.84) was dissolved in RPMI 1640 medium as $5 \mathrm{mM}$ solution. All-trans-retinoic acid (ATRA, Sigma-ALDRICH) was dissolved in ethanol as $100 \mu \mathrm{M}$ solution. Pan-caspase inhibitor ZVAD-FMK (627610) was from Merck \& Co. Inc. Bortezomib was from Millennium Pharmaceuticals (Cambridge, MA, USA). The primary antibodies against $\beta$-actin (13E5, \#4970), anti-caspase-3 (8G10, \#9665), anti-caspase-8 (D35G2, \#4790), anti-caspase-9 Antibody (\#9502), anti-PARP Antibody (\#9542), anti-Bcl-2 (D55G8, \#4223), anti-Bax (D2E11, \#5023), anti-Bcl-xL (54H6, \#2764) were from Cell Signaling (Beverly, MA, USA). Mouse monoclonal anti-PML Protein (ab57276) was from Abcam (Hongkong). The secondary antibody ImmunoPure Goat Anti-Rabbit IgG (\#31460) was from Thermo Scientific 
(USA). Goat anti-mouse IgG (PB001) was from Shanghai Immune Biotech Ltd (ImB, CHINA). Chemiluminescence phototope-horseradish peroxidase kit (WBKLS0100) was from Millipore (Germany).

\section{Cell lines, cell viability and cell morphology}

Human APL leukemia cell lines NB4 (retinoic acidsensitive), NB4-R1 and NB4-R2 cells (retinoic acidresistant) were kindly provided by Professor Michel Lanotte at Saint Louis Hospital in France. Acute myeloid leukemia cell lines Kasumi-1, K562 and U937 were available from American Type Culture Collection. Cells were cultured in RPMI 1640 medium, supplemented with $10 \%$ heat-inactivated fetal bovine serum (GIBCO-BRL), $100 \mathrm{U} / \mathrm{mL}$ penicillin and $100 \mathrm{mg} / \mathrm{mL}$ streptomycin (GIBCO-BRL), in $5 \% \mathrm{CO}_{2}-95 \%$ air humidified atmosphere at $37^{\circ} \mathrm{C}$. Fresh leukemia cells from the bone marrow of three APL patients were enriched by Ficoll separation. The diagnosis was established on the basis of morphological examination, presence of $t(15 ; 17)$ by cytogenetic study and PML-RAR $\alpha$ fusion gene by molecular analysis. CD34 ${ }^{+}$cells were purified from human cord blood by density gradient centrifugation. Informed consent was obtained according to institutional guidelines. Cell viability was assessed by triplicate counting of trypan blue dye-excluding cells under light microscopy. Cell morphology was evaluated by Wright's staining of cells prepared by cytospin centrifugation.

\section{MTT reduction assay}

A total of $5 \times 10^{4}$ cells per well were seeded in a 96-well plate, and treated with Catechins at concentrations of $25,50,100,200$ or $400 \mu \mathrm{M}$ for different time $(24 \mathrm{~h}, 48 \mathrm{~h}$ or $72 \mathrm{~h}$ ). After treatment, $0.1 \mathrm{mg}$ MTT was added to each well. The samples were incubated for 4 hours and the absorbance (optical density, OD value) was measured at $490 \mathrm{~nm}$ by spectrophotometry. Calculation of the cell growth inhibition rate at different concentrations is done by comparing it against the growth rate of untreated control group. Inhibition rate $=[1-$ OD value of treated cell/OD value of control cell] $\times 100 \%$.

\section{Flow cytometric assays for Annexin-V/PI, nuclear DNA contentdistribution, mitochondrial trans-membrane potentials, mitochondrial cytochrome $\mathrm{c}$, and reactive oxygen species (ROS) detection}

A total of $2 \times 10^{5}$ cells was analyzed using an Annexin V-FITC/PI apoptosis detection kit II (BD Pharmingen ${ }^{\text {tw }}$, Franklin Lakes, NJ, USA) according to manufacturer's instructions. To assess the distribution of nuclear DNA content, cells were collected, washed in PBS and fixed overnight in $75 \%$ ethanol at $-20^{\circ} \mathrm{C}$, treated with $1 \%$ RNase A for at least $15 \mathrm{~min}$ at $37^{\circ} \mathrm{C}$, and stained with 50 $\mu \mathrm{g} / \mathrm{ml}$ PI. For mitochondrial trans-membrane potential assessment, $1 \times 10^{6}$ cells were washed twice with PBS, incubated with $10 \mu \mathrm{g} / \mathrm{mL}$ of Rh123 for $30 \mathrm{~min}$ at $37^{\circ} \mathrm{C}$, and stained with $50 \mu \mathrm{g} / \mathrm{mL}$ of PI. Mitochondrial cytochrome c was measured by FlowCellect ${ }^{\text {tw }}$ cytochrome c kit (Millipore) according to manufacturer's protocols. To measure ROS levels, $5 \times 10^{5}$ cells were washed with RPMI1640 and incubated with $5 \mu \mathrm{M}$ DCFH-DA for $30 \mathrm{~min}$ at $37^{\circ} \mathrm{C}$. The fluorescent intensity was measured by flow cytometry (Becton Dickinson, San Jose, CA, USA). All experiments were performed in triplicate and data were collected, stored, and analyzed by Lysis 11 software (Becton Dickinson).

\section{Western blot analysis}

Western blot analysis was performed according to standard protocols. Approximately $5 \times 10^{6}$ cells were harvested and incubated in $100 \mu \mathrm{L}$ lysis buffer $[50 \mathrm{mM}$ Tris (pH 7.4), $150 \mathrm{mM} \mathrm{NaCl}, 1 \%$ Triton X-100, 1\% deoxycholate, $0.1 \% \mathrm{SDS}$ )] to prepare total protein samples. Equal amounts of protein $(20 \mu \mathrm{g})$ were separated by SDS-PAGE on $10 \%$ gels and transferred on to PVDF membrane (Millipore), and blocked with 5\% non-fat dried milk in TBST [phosphate-buffered saline- $0.05 \%$ Tween] at room temperature for $60 \mathrm{~min}$. The membranes were subjected to immunoblot analyses with appropriate primary antibody followed by horseradish peroxidase-linked secondary antibody. The immunocomplexes were visualized using chemiluminescence phototype-horseradish peroxidase kit.

\section{Terminal deoxytransferase-catalyzed DNA nick-end labeling (TUNEL) assay}

In situ tumor cell apoptosis was performed on deparaffinized $5 \mu \mathrm{m}$ thick sections using TdT-FragEL ${ }^{\mathrm{mm}}$ DNA Fragmentation Detection Kit (Merck, Germany) according to the manufacturer's recommendation. For quantification, three different fields were counted under light microscopy and at least 500 cells were enumerated in each field. All experiments were performed in triplicate.

\section{APL murine model}

Murine xenograft APL model was established by NB4 cells inoculation in nude mice. Briefly, mice were pretreated with $3 \mathrm{~Gy}$ of total body irradiation, which is a sublethal dose that was expected to enhance the acceptance of xenografts. Subsequently, NB4 cells $\left(1 \times 10^{7}\right)$ were inoculated subcutaneously into the right flank of nude mice (male, 5-6 weeks of age). Inoculated NB4 cells formed subcutaneous tumors at the injection site from 6-8 days. Ten days after cell inoculation, mice were randomly divided into two groups, and received water $(n=5)$ or Catechins $(10 \mathrm{mM}, \mathrm{n}=5)$ as the sole drinking treated for 21 days. Tumor volumes were calculated by the formula: $0.5 \times \mathrm{a} \times \mathrm{b} 2$ in millimeters, where ' $\mathrm{a}$ ' is the length 
and ' $b$ ' is the width. Tissue samples were fixed in formaldehyde and further embedded in paraffin.

\section{Statistical analysis}

All the results were expressed as the mean \pm S.D. and determined using t-test to compare variance. Survival functions were estimated using the Kaplan-Meier method and compared by the log-rank test. $\mathrm{P}$ value $<0.05$ were considered statistically significant. All statistical analyses were evaluated using the SPSS for Windows, Version 18.0.

\section{Abbreviations}

APL: Acute promyelocytic leukemia; PML: Promyelocytic leukemia; ATRA All-trans retinoic acid; $\mathrm{As}_{2} \mathrm{O}_{3}$ : Arsenic trioxide; EGCG: Epipallocatechin gallate: EC: Epicatechin; ECG: Epicatechin gallate; EGC: Epigallocatechin; MTT assays: 3-[4,5-dimethylthiazol-2-yl]-2,5 diphenyl tetrazolium bromide assays; IC50: The half maximal inhibitory concentration; $\Delta \psi \mathrm{m}$ : Mitochondrial trans-membrane potential; ROS: Reactive oxygen species; TUNEL: Terminal deoxytransferase-catalyzed DNA nick-end labeling assay.

\section{Competing interests}

The authors declare that they have no competing interests.

\section{Authors' contributions}

LZ, QSC, XD and YZ performed the research, LZ and WLZ designed the research study, PPX, YQ, AHW, YS and XQW analyzed the data, and WLZ wrote the paper. All authors have read and approved the final manuscript.

\section{Acknowledgments}

The work was supported, in part, by the National Natural Science Foundation of China (81325003 and 81201863), the Shanghai Commission of Science and Technology (11JC1407300 and 08411953900), and the Program of Shanghai Subject Chief Scientists (13XD1402700).

Received: 17 June 2014 Accepted: 23 September 2014

Published online: 01 October 2014

\section{References}

1. Chen Z, Wang ZY, Chen SJ: Acute promyelocytic leukemia: cellular and molecular basis of differentiation and apoptosis. Pharmacol Ther 1997, 76(1-3):141-149

2. Dong S, Tong JH, Huang W, Chen SJ, Chen Z, Wang ZY, Geng JP, Qi ZW: Molecular study on the chromosome 15 breakpoints in the translocation $\mathrm{t}(15 ; 17)$ in acute promyelocytic leukemia (APL). Sci China B 1993, 36(9):1101-1109.

3. Hu J, Liu YF, Wu CF, Xu F, Shen ZX, Zhu YM, Li JM, Tang W, Zhao WL, Wu W, Sun HP, Chen QS, Chen B, Zhou GB, Zelent A, Waxman S, Wang ZY, Chen SJ, Chen Z: Long-term efficacy and safety of all-trans retinoic acid/ arsenic trioxide-based therapy in newly diagnosed acute promyelocytic leukemia. Proc Natl Acad Sci U S A 2009, 106(9):3342-3347.

4. Wang ZY, Chen Z: Acute promyelocytic leukemia: from highly fatal to highly curable. Blood 2008, 111(5):2505-2515.

5. Shen ZX, Shi ZZ, Fang J, Gu BW, Li JM, Zhu YM, Shi JY, Zheng PZ, Yan H, Liu YF, Chen Y, Shen Y, Wu W, Tang W, Waxman S, De Thé H, Wang ZY, Chen SJ, Chen Z: All-trans retinoic acid/As2O3 combination yields a high quality remission and survival in newly diagnosed acute promyelocytic leukemia. Proc Natl Acad Sci U S A 2004, 101(15):5328-5335.

6. Wang ZY: Ham-Wasserman lecture: treatment of acute leukemia by inducing differentiation and apoptosis. Hematology Am Soc Hematol Educ Program 2003, 2003(1):1-13.

7. Wang ZY: Mechanism of action of all-trans retinoic acid and arsenic trioxide in the treatment of acute promyelocytic leukemia. Gan to kagaku nyoho Cancer \& chemotherapy 2002, 29(Suppl 1):214-218.

8. Zhao WL, Chen SJ, Shen Y, Xu L, Cai X, Chen GQ, Shen ZX, Chen Z, Wang ZY: Treatment of acute promyelocytic leukemia with arsenic trioxide: clinical and basic studies. Leuk Lymphoma 2001. 42(6):1265-1273.
9. Wang ZY: Arsenic compounds as anticancer agents. Cancer Chemother Pharmacol 2001, 48(Suppl 1):S72-S76.

10. Chen GQ, Zhu J, Shi XG, Ni JH, Zhong HJ, Si GY, Jin XL, Tang W, Li XS, Xong SM, Shen ZX, Sun GL, Ma J, Zhang P, Zhang TD, Gazin C, Naoe T, Chen SJ, Wang ZY, Chen Z: In vitro studies on cellular and molecular mechanisms of arsenic trioxide (As203) in the treatment of acute promyelocytic leukemia: As2O3 induces NB4 cell apoptosis with downregulation of $\mathrm{BCl}-2$ expression and modulation of PML-RAR alpha/PML proteins. Blood 1996, 88(3):1052-1061.

11. Chen Z, Tong JH, Dong S, Zhu J, Wang ZY, Chen SJ: Retinoic acid regulatory pathways, chromosomal translocations, and acute promyelocytic leukemia. Genes Chromosomes Cancer 1996, 15(3):147-156.

12. Chen SJ, Wang ZY, Chen Z: Acute promyelocytic leukemia: from clinic to molecular biology. Stem Cells 1995, 13(1):22-31.

13. Chen Z, Chen SJ, Wang ZY: Retinoic acid and acute promyelocytic leukemia: a model of targetting treatment for human cancer. C R Acad Sci III 1994, 317(12):1135-1141.

14. Mukhtar $\mathrm{H}$, Ahmad N: Tea polyphenols: prevention of cancer and optimizing health. Am J Clin Nutr 2000, 71 (6 Suppl):1698S-1702S. discussion 1703S-1694S.

15. Mitscher LA, Jung M, Shankel D, Dou JH, Steele L, Pillai SP: Chemoprotection: a review of the potential therapeutic antioxidant properties of green tea (Camellia sinensis) and certain of its constituents. Med Res Rev 1997, 17(4):327-365.

16. Stuart EC, Scandlyn MJ, Rosengren RJ: Role of epigallocatechin gallate (EGCG) in the treatment of breast and prostate cancer. Life Sci 2006, 79(25):2329-2336.

17. Horie N, Hirabayashi N, Takahashi Y, Miyauchi Y, Taguchi H, Takeishi K: Synergistic effect of green tea catechins on cell growth and apoptosis induction in gastric carcinoma cells. Biol Pharm Bull 2005, 28(4):574-579.

18. Porath D, Riegger C, Drewe J, Schwager J: Epigallocatechin-3-gallate impairs chemokine production in human colon epithelial cell lines. J Pharmacol Exp Ther 2005, 315(3):1172-1180.

19. Ran ZH, Zou J, Xiao SD: Experimental study on anti-neoplastic activity of epigallocatechin-3-gallate to digestive tract carcinomas. Chin Med J 2005, 118(16):1330-1337.

20. Ravindranath MH, Saravanan TS, Monteclaro CC, Presser N, Ye X, Selvan SR Brosman S: Epicatechins purified from green tea (Camellia sinensis) differentially suppress growth of gender-dependent human cancer cell lines. Evidence-based complementary and alternative medicine: ECAM 2006, 3(2):237-247.

21. Sah JF, Balasubramanian S, Eckert RL, Rorke EA: Epigallocatechin-3-gallate inhibits epidermal growth factor receptor signaling pathway. Evidence for direct inhibition of ERK1/2 and AKT kinases. J Biol Chem 2004, 279(13):12755-12762.

22. Nam S, Smith DM, Dou QP: Ester bond-containing tea polyphenols potently inhibit proteasome activity in vitro and in vivo. J Biol Chem 2001, 276(16):13322-13330.

23. Suganuma M, Okabe S, Kai Y, Sueoka N, Sueoka E, Fujiki H: Synergistic effects of (--)-epigallocatechin gallate with (--)-epicatechin, sulindac, or tamoxifen on cancer-preventive activity in the human lung cancer cell line PC-9. Cancer Res 1999, 59(1):44-47.

24. Fang MZ, Wang Y, Ai N, Hou Z, Sun Y, Lu H, Welsh W, Yang CS: Tea polyphenol (-)-epigallocatechin-3-gallate inhibits DNA methyltransferase and reactivates methylation-silenced genes in cancer cell lines. Cancer Res 2003, 63(22):7563-7570

25. Katiyar SK, Afaq F, Azizuddin K, Mukhtar H: Inhibition of UVB-induced oxidative stress-mediated phosphorylation of mitogen-activated protein kinase signaling pathways in cultured human epidermal keratinocytes by green tea polyphenol (-)-epigallocatechin-3-gallate. Toxicol Appl Pharmacol 2001, 176(2):110-117.

26. Jung YD, Ellis LM: Inhibition of tumour invasion and angiogenesis by epigallocatechin gallate (EGCG), a major component of green tea. Int J Exp Pathol 2001, 82(6):309-316.

27. Qian Y, Zhang L, Chen Q-S, Zhang Y, Xiao D, Wen X-Q, Zhao W-L: Catechins induce apoptosis of multiple myeloma RPMI 8226 cells and its mechanism. Tumor 2012, 32(1):1-6.

28. Oxidation-triggered c-Jun $\mathrm{N}$-terminal kinase (JNK) and p38 mitogenactivated protein (MAP) kinase pathways for apoptosis in human leukaemic cells stimulated by epigallocatechin-3-gallate, Pillai SP, Mitscher LA, Menon SR, Pillai CA, Shankel DM: Antimutagenic/antioxidant activity of green tea 
components and related compounds. J Environ Pathol Toxicol Oncol 1999, 18(3):147-158.

29. Riazantseva NV, Novitskii W, Kaigorodova EV, Chasovskikh N, Starikova EG: Mitogenactivated protein kinases JNK and p38 as redox-dependent molecular targets correction of programmed cell death disturbances in oxidative stress condition. Usp Fiziol Nauk 2009, 40(2):3-11.

30. Lee YK, Bone ND, Strege AK, Shanafelt TD, Jelinek DF, Kay NE: VEGF receptor phosphorylation status and apoptosis is modulated by a green tea component, epigallocatechin-3-gallate (EGCG), in B-cell chronic lymphocytic leukemia. Blood 2004, 104(3):788-794.

31. Nakagawa H, Hasumi K, Woo JT, Nagai K, Wachi M: Generation of hydrogen peroxide primarily contributes to the induction of $\mathrm{Fe}$ (II)-dependent apoptosis in Jurkat cells by (-)-epigallocatechin gallate. Carcinogenesis 2004, 25(9):1567-1574

32. Nakazato T, Ito K, Ikeda Y, Kizaki M: Green tea component, catechin, induces apoptosis of human malignant $B$ cells via production of reactive oxygen species. Clin Cancer Res 2005, 11(16):6040-6049.

33. de Mejia EG, Ramirez-Mares MV, Puangpraphant S: Bioactive components of tea: cancer, inflammation and behavior. Brain Behav Immun 2009, 23(6):721-731

34. Zhu J, Shi XG, Chu HY, Tong JH, Wang ZY, Naoe T, Waxman S, Chen SJ, Chen Z: Effect of retinoic acid isomers on proliferation, differentiation and PML relocalization in the APL cell line NB4. Leukemia 1995 9(2):302-309.

35. Lanotte M, Martin-Thouvenin V, Najman S, Balerini P, Valensi F, Berger R: NB4, a maturation inducible cell line with $\mathrm{t}(15 ; 17)$ marker isolated from a human acute promyelocytic leukemia (M3). Blood 1991, 77(5):1080-1086.

36. Ruchaud S, Duprez E, Gendron MC, Houge G, Genieser HG, Jastorff B, Doskeland SO, Lanotte M: Two distinctly regulated events, priming and triggering, during retinoid-induced maturation and resistance of NB4 promyelocytic leukemia cell line. Proc Natl Acad Sci U S A 1994, 91(18):8428-8432.

37. Kroemer $\mathrm{G}$ : The proto-oncogene $\mathrm{BCl}-2$ and its role in regulating apoptosis. Nat Med 1997, 3(6):614-620.

38. Li W, Nie S, Yu Q, Xie M: (-)-Epigallocatechin-3-gallate induces apoptosis of human hepatoma cells by mitochondrial pathways related to reactive oxygen species. J AgricFood Chem 2009, 57(15):6685-6691.

39. Manohar M, Fatima I, Saxena R, Chandra V, Sankhwar PL, Dwivedi A: (-)-Epigallocatechin-3-gallate induces apoptosis in human endometrial adenocarcinoma cells via ROS generation and p38 MAP kinase activation. J Nutr Biochem 2013, 24(6):940-947.

40. Yang WH, Fong YC, Lee CY, Jin TR, Tzen JT, Li TM, Tang CH: Epigallocatechin3-gallate induces cell apoptosis of human chondrosarcoma cells through apoptosis signal-regulating kinase 1 pathway. J Cell Biochem 2011, 112(6):1601-1611.

41. Shirakami Y, Shimizu M, Adachi S, Sakai H, Nakagawa T, Yasuda Y, Tsurumi H, Hara Y, Moriwaki H: (-)-Epigallocatechin gallate suppresses the growth of human hepatocellular carcinoma cells by inhibiting activation of the vascular endothelial growth factor-vascular endothelial growth factor receptor axis. Cancer Sci 2009, 100(10):1957-1962.

42. Abou E, Naga RN, Azab SS, El-Demerdash E, Shaarawy S, El-Merzabani M, el Ammar SM: Sensitization of TRAIL-induced apoptosis in human hepatocellular carcinoma HepG2 cells by phytochemicals. Life Sci 2013 , 92(10):555-561. 21.

43. Kim CY, Lee C, Park GH, Jang JH: Neuroprotective effect of epigallocatechin-3-gallate against beta-amyloid-induced oxidative and nitrosative celldeath via augmentation of antioxidant defense capacity Arch Pharm Res 2009, 32(6):869-881.

44. Wang Y, Ren X, Deng C, Yang L, Yan E, Guo T, Li Y, Xu MX: Mechanism of the inhibition of the STAT3 signaling pathway by EGCG. Oncol Rep 2013 30(6):2691-2696.

45. Maurizio G, Andrea B, Valeria G, Alessandro R, Edoardo P, Ivan R Jr, Cecile RE, Giannino DS, Alessandra R, Mineko T, Enrico G: Inhibition of the Peptidyl-prolyl-isomerase Pin1 enhances the responses of acute myeloid leukemia cells to retinoic acid via stabilization of RARA and PML-RARA. Cancer Res 2009, 69:1016-1026.

46. Gianni M, Peviani M, Bruck N, Rambaldi A, Borleri G, Terao M, Kurosaki M, Paroni G, Rochette-Egly C, Garattini E: p38aMAPK interacts with and inhibits RARa: suppression of the kinase enhances the therapeutic activity of retinoids in acute myeloid leukemia cells. Leukemia 2012, 26:1850-1861.
47. Pisters KM, Newman RA, Coldman B, Shin DM, Khuri FR, Hong WK, Glisson BS, Lee JS: Phase I trial of oral green tea extract in adult patients with solid tumors. J Clin Oncol 2001, 19(6):1830-1838.

48. Crew KD, Brown P, Greenlee H, Bevers TB, Arun B, Hudis C, McArthur HL, Chang J, Rimawi M, Vornik L, Cornelison TL, Wang A, Hibshoosh H, Ahmed A, Terry MB, Santella RM, Lippman SM, Hershman DL: Phase IB randomized, double-blinded, placebo-controlled, dose escalation study of polyphenon $\mathrm{E}$ in women with hormone receptor-negative breast cancer. Cancer Prev Res 2012, 5(9):1144-1154.

49. Zhao H, Zhu W, Xie P, Li H, Zhang X, Sun X, Yu J, Xing L: A phase I study of concurrent chemotherapy and thoracic radiotherapy with oral epigallocatechin-3-gallate protection in patients with locally advanced stage III non-small-cell lung cancer. Radiother Oncol 2014, 110(1):132-136.

\section{doi:10.1186/s13045-014-0075-3}

Cite this article as: Zhang et al:: Catechins induced acute promyelocytic leukemia cell apoptosis and triggered PML-RARa oncoprotein degradation. Journal of Hematology \& Oncology 2014 7:75.

\section{Submit your next manuscript to BioMed Central and take full advantage of:}

- Convenient online submission

- Thorough peer review

- No space constraints or color figure charges

- Immediate publication on acceptance

- Inclusion in PubMed, CAS, Scopus and Google Scholar

- Research which is freely available for redistribution

Submit your manuscript at www.biomedcentral.com/submit
C BioMed Central 